\title{
Genetic Variability Estimation and Frequency of Superior Progenies in Advance Breeding lines in desi cotton at two locations
}

\author{
BANGAREMMA S. WADEYAR ${ }^{\star}$ and S.T. KAJJIDONI \\ Department of Genetics and Plant Breeding, \\ University of Agricultural Sciences, Dharwad 580005, India. \\ http://dx.doi.org/10.12944/CWE.10.1.39
}

(Received: December 13, 2014; Accepted: January 21, 2015)

\begin{abstract}
Two hundred and two progenies were evaluated at two locations viz., Agricultural Research Station, Annigeri and Main Agricultural Research Station, Dharwad to estimate genetic variability and to identify superior progenies for seed cotton yield, yield contributing and fibre quality traits. The analysis of variance revealed presence of sufficient variability in the material for seven traits at both locations. High phenotypic coefficient of variation (PCV) and genotypic coefficient of variation (GCV) were recorded for number of bolls per plant and seed cotton yield per plant, while, moderate variability estimate was recorded for plant height and low PCV and GCV were noticed for boll weight, ginning out turn, seed index and lint index traits at both the locations. High heritability was observed for seed index exhibited 97 per cent with moderate genetic advance as percent mean (GAM) at both the locations. High GAM was observed for number of bolls per plant, seed cotton yield and plant height. Moderate GAM was noticed for boll weight and seed index traits at both locations. An attempt was made to identify superior progenies, maximum number of superior progenies were observed for seed cotton yield at Dharwad (33 progenies) followed by Annigeri (24 progenies).
\end{abstract}

Key words: Desi, Frequency, GCV, Heritability, Locations and PCV.

\section{INTRODUCTION}

Cotton, popularly referred as "White Gold", is an important fibre crop of global importance, cultivated in tropical and sub-tropical regions of more than seventy countries. Its importance in our economy is reflected in terms of generating employment, and foreign exchange earnings. Cotton is the lifeline for about 60 million people, which includes farmers and workers involved in the cotton industry from processing to trading (Khadi, 2007). Global production of cotton is 26.14 million tons of which India contributes 8.5 million tons amounting to 32.5 per cent world share. India is the second highest producer of cotton (lint) next to china. In India, about 90 per cent area is covered by hirsutum hybrids, 8 per cent by Egyptian varieties and 2 per cent by diploid cultivars (Anon, 2014). The area under cotton during 2012-13 in India was 11.978 lakh hectare with production and productivity of 365 lakh bales and $518 \mathrm{~kg}$ lint per hectare respectively and in the same year in Karnataka, cotton was grown over an area of 4.85 lakh hectare with a production of 15.00 lakh bales and productivity of $526 \mathrm{~kg} / \mathrm{ha}$ (Annon. 2014).

Development of an effective breeding programme depends on the existence of genetic variability for various economic characters in the gene pool. Selection is effective only when there is enough magnitude of variability in the breeding population. An understanding of precise magnitude of variability present among the progenies is 
important in formulating the most appropriate breeding technique for improvement of various characters. The present investigation was carried out with 202 G. herbaceum progeny lines to estimate their per se performance, variability, heritability and genetic advance on the genetic architecture of seven seed cotton yield and yield traits.

\section{MATERIALS AND METHODS}

The study was conducted at two locations viz., Agricultural Research Station, Annigeri and Main Agricultural Research Station, University of Agricultural Sciences, Dharwad. A total of two hundred and two advance breeding lines derived from irradiated $F_{5} M_{5}, M_{5}$, straight single crosses $F_{5}$ and double crosses $F_{4}$ progenies were used as experimental material to study the variability for seed cotton yield and yield component traits to assess variability parameters for quantitative traits in desi cotton. These progenies were advanced in their previous generation based on seed cotton yield and quality traits considering Jayadhar as check. A total of 202 progenies were planted in randomized block design with three replications at both the loctions. Uniform spacing of $60 \times 30 \mathrm{~cm}$ and all the recommended field operations were carried out. In each replication five competitive plants were randomly selected in each progeny line and observations were recorded for seven important seed cotton yield and yield attributing traits viz., plant height $(\mathrm{cm})$, number of bolls per plant, boll weight $(\mathrm{g})$, seed cotton yield per plant $(\mathrm{g})$, lint index $(\mathrm{g})$, seed index (g) and ginning outturn.

Analysis of variance was carried out separately at both the locations, according to Panse and Sukhtame (1995). The phenotypic and genotypic coefficient of variation was estimated using the formula suggested by Burton and Devane (1953) and expressed in percentage. Heritability, expected genetic advance and genetic gain in the broad sense was calculated according to the formula suggested by Johnson et al. (1955). The plant posing higher values than the mean plus one standard deviation for seed cotton yield, number of bolls per plant and boll weight (at both the locations). $2.5 \%$ span length and fiber strength (Annigeri location only) were identification as superior segregants and expressed in percentage.

\section{RESULTS AND DISCUSSION}

Phenotypic coefficient of variation (PCV), genotypic coefficient of variation (GCV), heritability in broad sense, genetic gain and genetic advance as percentage of mean (GAM) estimated for seven traits are shown in Table 1. The knowledge of nature and magnitude of variability available in the progenies for different traits is an important prerequisite for making simultaneous selection over more number of characters to bring remarkable improvement in desi cotton. The heritable (genotypic) variation is usually masked by non-heritable variation making selection much more complex.

\section{Seed cotton yield}

Seed cotton yield is a major factor governing economic worth and it is governed by several yield contributing traits such as number of bolls per plant, boll weight. High PCV, GCV, heritability, GA and GAM were recorded at both the test locations, while comparatively higher values were observed at Annigeri location for all the above mentioned genetic parameters. These difference may be due to the environment and weather conditions which suits for desi cotton at Annigeri location which favor overall expression of seed cotton yield and this location comes under a traditional area for cultivation of herbaceum cotton. The estimates of high heritability and GA suggest that simple phenotypic selection can be made to improve seed cotton yield per se. These results are in accordance with Ashok et al. (2000), observed wide variability in treated Jayadhar for various quantitative characters, and study conducted by Waghmore et al. (2000) noticed wide range of genetic variability in $\mathrm{M}_{2}$ and $\mathrm{M}_{3}$ population of G. arboreum for major yield contributing characters such as number of bolls per plant, number of fruiting branches and plant height, while Talwar and Kajjidoni (2008, 2009 and 2010) reported high variability estimates of majority of traits in desi cotton.

\section{Number of bolls per plant}

Number of bolls per plant is one of the important yield related traits in cotton which is most targeted trait to improve the seed cotton yield. Higher magnitude of PCV, GCV heritability and GAM estimates were recorded at both the test locations. However, the genetic gain was higher (20.99) at Annigeri location. Genetic gain can help to predict 


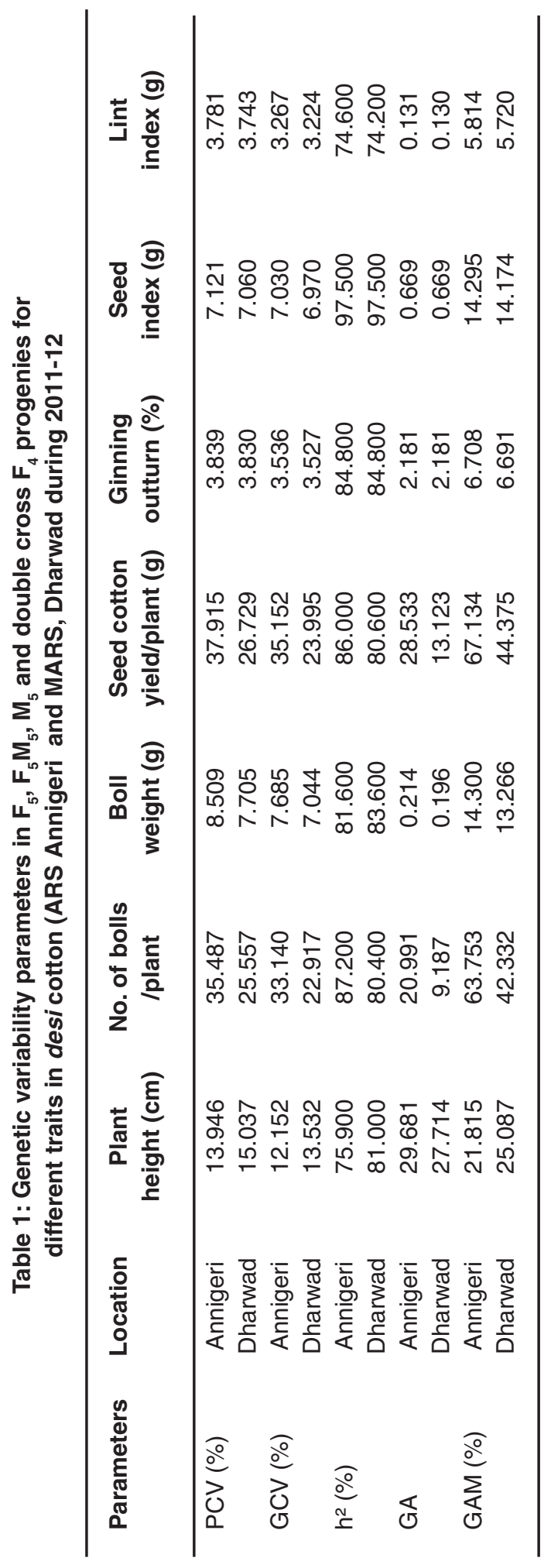

the extent of improvement that can be achieved for the trait. These results are in line with the results of Waghmore et al. (2000) and Talwar and Kajjidoni (2008, 2009 and 2010).

\section{Boll weight}

Boll weight is another important and crucial trait in deciding final yield after the number of bolls per plant trait. Since the desi cotton bear small bolls and harvesting of individual small bolls are time consuming and will not be cost effective. Hence, progenies bearing bigger boll size are preferred. In the present study, boll weight exhibited lower values of PCV, GCV and GA estimates in both the test locations revealed limited scope of selection for improvement of this trait. Further, narrow difference between PCV and GCV values at both the locations indicate lower influence of environment on this trait. High values of heritability were recorded with moderate values of GAM at both the locations indicating moderate response of trait for direct phenotypic selection. These results were in concurrent with the earlier findings made by Tommer et al. (1992) recorded moderate to high estimates of genetic variation, heritability and expected genetic advance for bolls per plant, seed cotton yield per plant, lint yield per plant and lint index in sixty $F_{1} s$ along with 23 parents of desi cotton.

\section{Plant height (cm)}

The variability parameters like PCV and GCV estimates exhibited a narrow difference at both the test locations which is the indication of the predominant role of genotype rather than the environment in the expression of plant height. However, among the two locations, these estimates were relatively higher at Dharwad compared to Annigeri. Further, it is interesting to note that the other variability parameters like heritability, GA and GAM estimates were of higher magnitude as per the classification at both the locations. These results suggest the existence of greater scope for selection of taller plant types in order to accommodate more number of branches and the fruiting points but such plants should be physiologically efficient in terms of water use efficiency (WUE) as desi cottons are grown mainly under rainfed condition. Similar findings with high genetic parameters for this trait were reported by Usha et al. (2005), irradiated genotypes showed higher seed cotton yield and improvement in other 
Table 2: Frequency of superior progenies for seed cotton yield and fiber quality traits (ARS Annigeri and MARS, Dharwad during 2011-12

\begin{tabular}{llccc}
\hline SI. No. Traits & $\begin{array}{c}\text { Number of } \\
\text { progenies }\end{array}$ & $\begin{array}{c}\text { Superior progenies based on mean } \\
\text { plus one standard deviation and their percentage }\end{array}$ \\
\cline { 3 - 5 } & & 202 & $27(13.37)$ & $28(13.86)$ \\
Annigeri location & Dharwad location \\
\hline 1. & Number of bolls/plant & 202 & $32(15.84)$ & $34(16.83)$ \\
2. & Boll wt (g) & $24(11.88)$ & $33(16.34)$ \\
3. & Seed cotton yield/plant (g) & 202 & 83 & 95 \\
& & Total & $29(15.68)$ & - \\
4. & $2.5 \%$ S. Length (mm) & 185 & $23(12.43)$ & - \\
5. & Tenacity (g/t) & 185 & 135 & 95 \\
\hline
\end{tabular}

Figures in parenthesis indicate percentage values.

yield attributes indicating that the gamma rays and EMS produced useful genotypes in desi cotton.

\section{GOT, Seed index and Lint index}

High seed index is mostly accompanied by boll weight and seed cotton yield per plant. Higher seed index value reduces the ginning out turn values. Lint index represents the absolute weight of the lint produced per seed and is highly correlated with lint yield. Lower estimates of both PCV and GCV were recorded under both the test locations for the ginning out turn, seed index and lint index traits indicating the narrow range of variability for these traits and in turn it restricts the scope of selection. High heritability for these traits indicated that these traits are generally governed by the additive gene effects. But the dominance of environmental factors was evident as these traits exhibited low GA and moderate to low GAM (seed index). So, the improvement of yield through yield components should be based not on simple selection alone but also on progeny test as cotton is highly plastic as far as the expression of morphological traits are considered.

\section{Frequency of superior progenies}

Judging the superiority of progenies based on parameters like mean and variability will not be that much valuable for effecting the selection. In the present study, superior progenies were identified as indicated in Table 2, for seed cotton yield and its component traits on the basis of their performance over mean with one standard deviation value.
The superior progenies were mainly identified for seed cotton yield per plant, number of bolls per plant, boll weight, $2.5 \%$ span length and tenacity traits. The number of superior progenies were more for boll weight $(15.8 \%)$, followed by $2.5 \%$ span length (15.7\%), number of bolls per plant $(13.4 \%)$, tenacity $(12.4 \%)$ and seed cotton yield $(11.9 \%)$, similar approach was used by Talwar and Kajjidoni (2010), wherein they observed maximum number of superior progenies for the traits like number of bolls per plant and seed cotton yield per plant.

Superior progenies were recorded at Dharwad where higher number of superior progenies were recorded for boll weight (16.8\%) followed by seed cotton yield per plant $(16 \%)$ and number of bolls per plant (13.8\%). Talwar and Kajjidoni (2010) to identify superior progenies for seed cotton yield and its attributes.

\section{CONCLUSION}

From this it can be concluded that variability present in the material can be exploited and the best performing progenies can be as donors in further breeding program to exploit the heterosis. And the progeny identified superior for seed cotton yield and yield related and fiber quality traits can be tested for its stability at many locations. 


\section{ACKNOWLEDGMENTS}

This work was conducted at two locations viz., Agricultural Research Station, Annigeri and
Main Agricultural Research Station, Dharwad, University of Agricultural Sciences, Dharwad. We would like to thank them for support and help.

\section{REFERENCES}

1. Anonymous, 2014, Area production and yield of Cotton. <http ://www. cottoncorporationofindia. org. html> accessed on 20/06/2014.

2. Ashok, M. B., Katageri, I. S., and Khadi, B. M., 2000, Effect of gamma rays and EMS on quantitative characters in cotton (Gossypium spp.). DAE BRNS Symposium, Mumbai, pp. 230-236.

3. Burton, G. W. and Devane, E. M., Estimating heritability in tall fescue (Festecd cirunclindcede) from replicated clonal material. Agron. J., 45 : 478-481 (1953).

4. Johnson, H. W., Robinson, H. F. and Comstock, R. E., Genotypic and phenotypic correlation in soybean and their implications in selection. Agron. J., 47 : 477-483 (1955).

5. Khadi, B. M., Rao, M. R. K. and Singh, M., The Hindu newspaper, (2007).

6. Panse, V. G. and Sukhatme, P. V., 1995, Statistical Methods for Agricultural Workers. $3^{\text {rd }}$ Ed., ICAR, New Delhi, p.58.

7. Talwar A. M. and Kajjidoni S. T., Induced Variability Studies on Productivity Related Traits in Desi Cotton. Karnataka J. Agric. Sci., 21 (4) : pp 666 (2008).

8. Talwar A. M. and Kajjidoni S. T., Frequency of superior segregants as influenced by hybridization $\left(F_{2}\right)$ and hybridization followed by irradiation $\left(\mathrm{F}_{2} \mathrm{M}_{2}\right)$ using selected parents for important component traits in desi cotton. Electronic J. Plant Breed., 1(4) : 675-679 (2010).

9. Talwar, M. and Kajjidoni, S. T., Impact of induced mutation on genetic variability, association and frequency of superior segregants in desi cotton (Gossypium herbaceum L.)]. Res. on Crops, 10 (3) : 647654 (2009).

10. Tomar, S. K., Singh, S. P. and Tomar, S. R. S., Genetic variability of yield and its components over environments in desi cotton (Gossypium arboreum L.). Crop Res., 5(2) : 290-293 (1992).

11. Usha and Singh, K. P., Induced mutants show genetic variability in quantitative characters of desi cotton (Gossypium arboreum) and American cotton (Gossypium hirsutum). J. Cotton Res. Dev., 19(2) : 170-173 (2005).

12. Waghmore, V. N., Gururajan, K. N., Punitmohan and Phundan Singh, Induced mutation for improvement of desi cotton. DAE-BRNS, Symposium, Mumbai, pp. 258-263 (2000). 